\title{
Transauthorial Screendance: Stravinsky's Exquisite Corpse, or Brief Notes on Creating an International Omnibus Project
}

Marisa C. Hayes, Co-director, Festival International de Vidéo Danse de Bourgogne/Body Cinéma

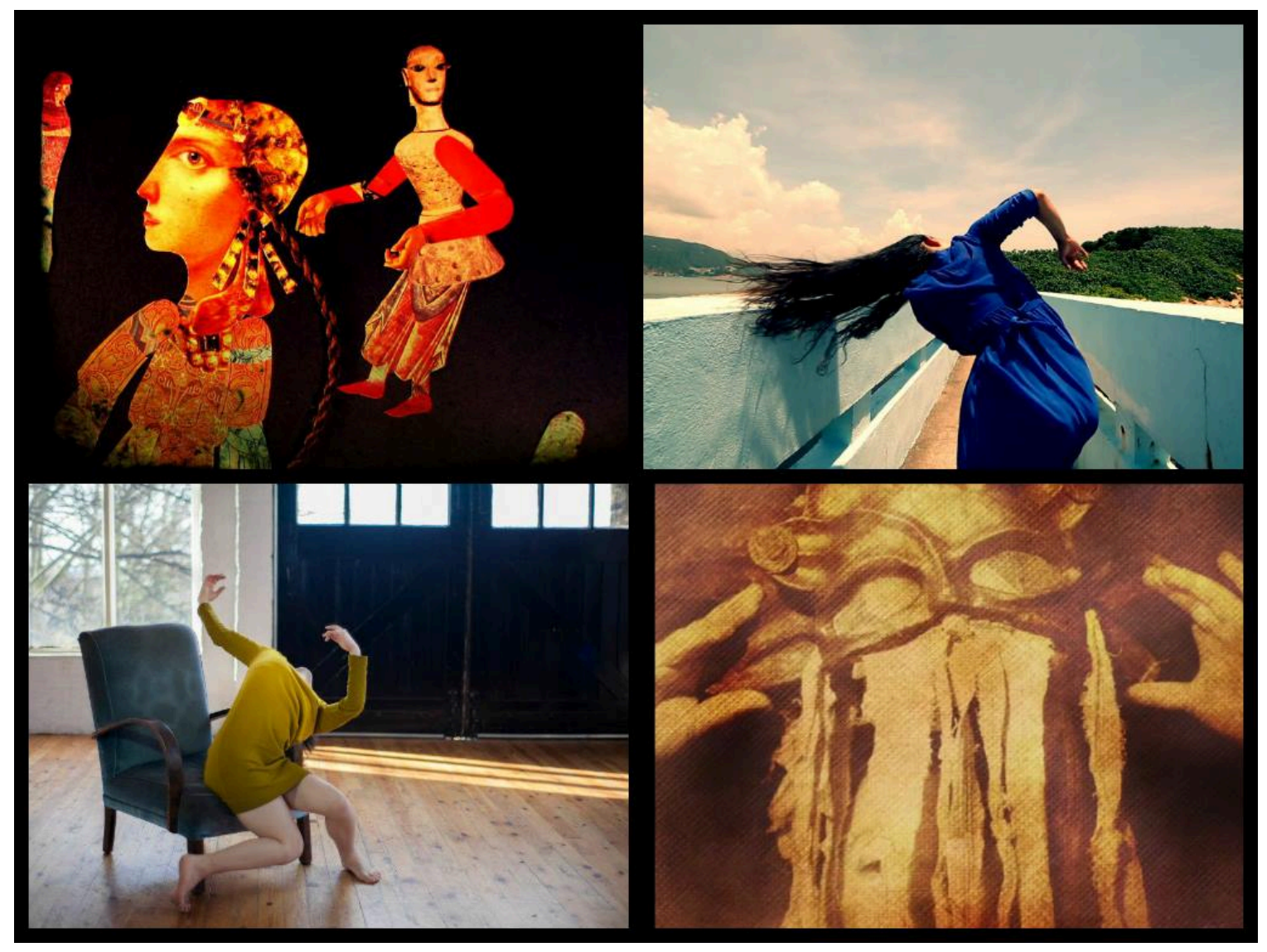

Four contributions to the Sacre/ilège(s) project by (top left to bottom right): Diana Heyne, Maurice Lai, Guy Wigmore and Franck Boulègue. Photo courtesy of Festival International de Vidéo Danse de Bourgogne/Body Cinéma

In honor of the first centenary surrounding the pivotal composition and ballet Le Sacre du Printemps (The Rite of Spring) in 2013, Franck Boulègue and I coordinated a collective screendance project entitled Sacre/ilege(s). Created in collaboration with 65 international artists, we sought to explore the ongoing presence of Le Sacre $d u$ 
Printemps internationally and to harness its wide reaching artistic influence in order to create an omnibus cycle of films. While hundreds of stage versions of Le Sacre du Printemps exist, ${ }_{1}{ }^{\text {it }}$ has rarely been imagined for the screen and is normally identified with an individual artist's vision (Stravinsky's music, Nijinsky or Pina Bausch's choreography, among others). Diverging from these familiar components seemed a fitting tribute to a production whose original look and sound shook the cultural landscape of its era, affecting multiple generations of artists thereafter. This provided the impetus for our first foray into transauthorial screendance and raised a number of questions on the nature of collaboration, community, and authorship: What forms of collaboration are possible for the screen today? Does collaboration itself form a community? Does collaboration represent a compromise on the part of the individual artist or does it simply construct a larger authorial composite? Despite the significance of these questions throughout the history of art-and moving images in particular ${ }^{2}$ these subjects are rarely addressed or explored at screendance platforms today.

Working with the Vienna Symphonic Library of Austria and Jay Bacal-who recreated Stravinsky's orchestral score of Le Sacre du Printemps on a computer-we divided the music into 13 sections that were assigned at random to international artists from a range of creative backgrounds who responded to the project's online open call. This simple process formed a virtual and intentional community of artists based on a shared interest in both Le Sacre du Printemps and the notion of creating a collective work. Artists committed to a project in which they are featured side by side as part of the same film is in contrast to the ubiquitous festival model, which typically features short works of screendance independent of one another. In addition to the work created, the project generated a number of unsolicited online exchanges among artists regarding research undertaken and responses to creating the project. Although rooted to an array of media and working styles, the artists' shared participation provided a foundation for communal dialogue across geographic boundaries and artistic practices, which begs the question, why are there not more opportunities to forge collaborative working relationships in the screendance community?

Project artists were given total liberty in the creation of their contributions save our request not to alter the music, which served, in this case, as a unifying feature. Upon completion, all portions of the film were assembled to create a full-length version of Le Sacre du Printemps. Due to the high number of participants, the project generated five complete cycles of the piece, a total of 65 film segments (or what anthology filmmakers ${ }^{3}$ call "episodes") from over 25 countries. Designated by the letters " $S$," " $A$," " $C$," " $R$," and " $E$," the five versions ${ }^{4}$ can be viewed interchangeably in a number of flexible formats, yet opportunities to screen or exhibit all five cycles together have been scarce based on the short films screening model common at most screendance platforms around the world. 
In addition to artists who regularly engage the term screendance to describe their practice, the project received contributions from both groups and individuals who identified as performance artists, video artists, filmmakers, animators, dancers, photographers, writers, students, sculptors, new media artists, or a combination of the above. As a result, the broad range of work featured in Sacre/ilege(s) provides not only a global panorama of contemporary screendance, but also reveals the diverse layers of media and practices that inform its complex and on-going histories. Indeed, our inspiration for creating an omnibus work of screendance can be traced to collective experiments from various media and eras, particularly the surrealist Exquisite corpse method and Miranda July's Joanie 4 Jackie VHS zine. ${ }^{5}$ The former began as a game in the early 2oth century to create two-dimensional drawings or writing experiments that assembled successive artists' contributions in a composite work. Miranda July's open participation project was a chain-letter series born of the 1990 D DIY film movement that involved compiling and distributing VHS anthologies of moving images contributed by women filmmakers. While the Exquisite corpse method represents a more traditional vision of collaboration and community in terms of physical interactions, ${ }^{6}$ Joanie 4 Jackie also sought to build an audience and artistic community utilizing the portability of video to spread its tagline, "You always suspected it and now you know it's true: girls and women are making movies every day."

In 1948 film theorist André Bazin harshly dismissed films composed of multiple sketches or episodes as "a bastard and phony type of film if ever there was one." ${ }^{77}$ Yet Bazin's emphasis on the individual filmmaker or "auteur"-which created his distaste for the omnibus model composed of multiple artistic contributions and perspectivesdownplays cinema's traditional collaborative nature. In the book Omnibus Films, David Scott Diffrient describes this as a failure to appreciate the "carnivalesque mishmashing of elements that has the latent capacity to level social fields, demolish aesthetic hierarchies, and provide alternative visions of life free from conventional rules and restrictions. ${ }^{\prime 8}$ Diffrient further states that omnibus films are hybrid productions by nature that thwart established filmmaking traditions by removing conceptual, thematic, and aesthetic boundaries: "such thresholds may be literal or figurative, spatial or corporeal..." ${ }^{9}$ He argues that omnibus cinema's transgressions offer a vast array of aesthetic, ideological, and structural perspectives, among others, that propose a "remarkable democratic alternative ${ }^{\prime 10}$ to filmic conventions. Omnibus films amass an array of artistic approaches that collectively allow the viewer "to taste the world, ${ }^{11}$ echoing the surrealists, particularly André Breton's statement on the Exquisite corpse:

What exalted us in these productions was indeed the conviction that, come what might, they bore the mark of something that could not be begotten by one mind alone and that they were endowed, in a much greater measure, with a power of drift that poetry cannot value too highly. ${ }^{12}$ 
These thoughts reflect one of the Sacre/ilege(s) project's central goals that resulted in its open participation policy towards artists of all media and levels of experience.

Sacre/ilège(s) is, to our knowledge, the first omnibus work of screendance and a model we intend to continue exploring through future collaborations (including plans for a Danses Macabres omnibus in 2015/16). The project has drawn mixed reactions from audiences, some of whom echo conventional dissatisfaction with transauthorial projects described in Omnibus Films, focusing on what they perceive as a lack of consistency or unified artistic vision. We would argue, like Diffrient, that the omnibus film presents "intratextual complexities"13 affording audiences the opportunity to consider multiple visions and approaches within the screendance community. Omnibus and other collective projects can in fact be unified through their lack of uniformity, creating a space to be "imaginatively inhabited" ${ }^{14}$ by audiences and appreciated as a dynamic network of exchange. While Sacre/ilège(s) was certainly not an attempt to create a community of artists based on any single shared aesthetic or working method, it was an exploration that engaged the collective sharing of artistic processes, research, and screen space. How might screendance benefit (or not) from the Dadaist stance that the value of art is not in the work produced, but in the act of making and collaborating?

While each contribution to the Sacre/ilège(s) project could potentially be viewed alone, each film as a whole would be visibly incomplete if one portion were to be removed. The 13 episodes that comprise each cycle of the project therefore collectively occupy a space often deemed a site of single residency (auteur theory ${ }^{15}$ ). As individual short films continue to dominate the screendance festival model-an approach that rarely demonstrates curatorial strategies or innovative presentation formats that encourage meaningful dialogue-it is long overdue to not only ask, but to actively explore alternate reflections of the screendance community. Instead of presenting separate films as if they existed in a vacuum, how can screendance programs reflect shared themes, research, collaboration, spheres of influence, spaces, and/or working methods, among others? In lieu of eschewing seemingly incongruent practices and/or media, screendance curators, artists and viewers must collaborate to facilitate experiences that allow for deeper study and an inclusive definition of screendance for it to thrive. The alternative is stagnation within the same hegemonic format, thereby limiting both the art form itself and the possibility of fostering a wider community of scholars, viewers, and artists.

\section{Biography}

Marisa C. Hayes is an artist, writer and curator whose work explores the intersections of experimental filmmaking, choreography and literature. She is the founding co-director 
of the International Video Dance Festival of Burgundy and Body Cinéma, a dancetheatre company. Her screendance collaborations with Franck Boulègue have been featured at festivals and galleries in over 20 countries and received a Susan Braun Award from the New York Dance Films Association and Pentacle Movement Media's video dance prize. Marisa's writing on screendance, dance history and film studies has been published in a variety of books and journals in the UK, USA and France.

\section{Notes}

${ }^{1}$ See Stephanie Jordan and Larraine Nicholas' database, Stravinsky the Global Dancer: http://ws1.roehampton.ac.uk/stravinsky/

${ }^{2}$ The question of authorship in moving images compared to other art forms is well explored in the section "Cinematic Authorship" in Gaut's A Philosophy of Cinematic Arts.

${ }^{3}$ Noteworthy collaborations that resonate with this article for their collective experimentation in multidisciplinary practices include the episodic films: Dreams That Money Can Buy (1947) and 8 x 8: A Chess Sonata in 8 Movements (1957). Produced and conceived by Hans Richter, artists such as Jean Cocteau, Marcel Duchamp, Alexander Calder, Fernand Léger, and Many Ray, among others, each contributed segments to the films.

${ }^{4}$ The five cycles of the project can be viewed online at the following links:

- S: https://www.youtube.com/watch?v=ipYMgQyBnAM

- A: https://www.youtube.com/watch?v=HZ21hy6J5HI

- C: https://www.youtube.com/watch?v=C3fh81Lhlel

- R: https://www.youtube.com/watch?v=H_puuBRmlro

- E: https://www.youtube.com/watch?v=wUZt_-IYDjs

${ }^{5}$ See http://www.joanie4jackie.com/

${ }^{6}$ The exquisite corpse method was originally derived from a parlor game. Its process of physical exchange is described throughout André Breton's Le Cadavre exquis, son exaltation.

${ }^{7}$ André Bazin, Qu'est-ce que le cinéma?, 332.

${ }^{8}$ Diffrient, Omnibus Films, 65.

${ }^{9}$ Ibid.

${ }^{10}$ Ibid.

${ }^{11}$ Idem., 66.

${ }^{12}$ André Breton quoted in La Revolution surréaliste, p.12.

${ }^{13}$ Diffrient, Omnibus Films, 32.

${ }^{14}$ Ibid.

${ }^{15}$ See Joël Magny's article "1953-1968: de la 'mise en scène' à la 'politique des auteurs."' 


\section{References}

8 x 8: A Chess Sonata in 8 Movements (1957). Dir. Hans Richter, Jean Cocteau, etc. 80:00 $\min ., 35 \mathrm{~mm}$, USA.

Bazin, André. Qu'est-ce que le cinéma? Paris: Editions du Cerf, 1978.

Breton, André. Le Cadavre exquis, son exaltation. Milan: Galleria Schwartz, 1975.

Breton, André. "Le Surréalisme et la peinture." La Revolution surréaliste 9 (October 1927): 38.

Diffrient, David Scott. Omnibus Films: Theorizing Transauthorial Cinema. Edinburgh : Edinburgh University Press, 2014.

Dreams That Money Can Buy (1947). Dir. Hans Richter, etc. 99:00 min., 16mm. USA.

Gaut, Berys. A Philosophy of Cinematic Arts. Cambridge: Cambridge University Press, 2010.

Jordan, Stephanie and Nicholas, Larraine. Stravinsky the Global Dancer: A Chronology of Choreography to the Music of Igor Stravinsky. Roehampton University, 2003. Web.

Accessed April 9, 2015.

July, Miranda. Joanie 4Jackie. Web. Accessed September 9, 2014.

Magny, Joël. "1953-1968: de la 'mise en scène' à la 'politique des auteurs."' CinémAction (1991): 86-90.

Sacre/ilège(s) S (2013). Dir. Body Cinéma/multiple directors. 36:25 min., digital video. France/multiple countries.

Sacre/ilège(s) A (2013). Dir. Body Cinéma/multiple directors. 36:25 min., digital video. France/multiple countries.

Sacre/ilège(s) C (2013). Dir. Body Cinéma/multiple directors. 36:25 min., digital video. France/multiple countries.

Sacre/ilège(s) R (2013). Dir. Body Cinéma/multiple directors. 36:25 min., digital video. France/multiple countries.

Sacre/ilège(s) E (2013). Dir. Body Cinéma/multiple directors. 36:25 min., digital video. France/multiple countries. 